PYTHAGORAS: Jurnal Pendidikan Matematika

Volume 10 - Nomor 2, Desember 2015, (201-210)

Available online at: http://journal.uny.ac.id/index.php/pythagoras

\title{
Pengembangan Perangkat Pembelajaran Matematika Berbasis Saintifik untuk Meningkatkan Kemampuan Pemecahan Masalah dan Prestasi Belajar Siswa
}

\author{
Siti Kawiyah \\ SMA Negeri 2 Yogyakarta. Jalan Bener 30, Yogyakarta, Indonesia. \\ Email: skawiyah@gmail.com
}

\begin{abstract}
Abstrak
Penilitian ini bertujuan untuk menghasilkan perangkat pembelajaran matematika berbasis saintifik untuk meningkatkan kemampuan pemecahan masalah dan prestasi belajar siswa kelas $\mathrm{X}$ di SMA semester 2. Jenis penelitian ini adalah penelitian pengembangan (Research and Development). Penelitian ini mengembangkan perangkat pembelajaran dengan menggunakan model pengembangan 3D (Define, Design, Develop) yang dikembangkan oleh Borg dan Gall. Subjek penelitian ini adalah 136 siswa kelas X SMA Negeri 2 Yogyakarta. Analisis data dilakukan dengan mengkonversi total skor aktual yang diperoleh menjadi data kualitatif skala lima. Penelitian ini menghasilkan perangkat pembelajaran matematika materi persaman kuadrat, fungsi kuadrat dan peluang yang, meliputi RPP, LKS, TPB dan TKPM. Dari hasil validasi ahli, skor penilaian guru, penilaian siswa, observasi pembelajaran dan tes evaluasi menunjukkan bahwa RPP, LKS, TPB dan TKPM adalah valid, praktis, dan efektif. Secara keseluruhan hasil penelitian menunjukkan bahwa perangkat pembelajaran yang dikembangkan adalah layak untuk digunakan.
\end{abstract}

Kata kunci: pengembangan, perangkat pembelajaran saintifik, prestasi, pemecahan masalah

\section{Development of Scientific-Based Mathematics Learning Resources for Enhancing Problem Solving Ability and Student Learning Achievement}

\begin{abstract}
This research's aim is to produce scientific-based mathematic learning kit to enhancing problem solving ability and student leaing achievement in 2ndsemester of 10th grade highschool student. This research's type is research and development. This research evolving learning resources with 3D development model: Define, Design, and Develop that developed by Borg and Gall. This research's subject were 136 students grade 10th in SMAN 2 Yogyakarta. Data analysis using conversion of all actual score that reputed as five scale qualitative data. This research produce learning resources of quadratic agreement, quadratic function, and possibility that include teaching plan (RPP), student's worksheets (LKS), student's achievement test (TPB), and problem solving ability test (TKPM) that valid, practical, and effective. Overall, this research's result showing that learning resources are suitable for using in class.
\end{abstract}

Keywords: development, scientific learning kit, achievement, problem solving.

How to Cite Item: Kawiyah, S. (2015). Pengembangan perangkat pembelajaran matematika berbasis saintifik untuk meningkatkan kemampuan pemecahan masalah dan prestasi belajar siswa. PYTHAGORAS: Jurnal Pendidikan Matematika, 10(2), 201-210. doi:http://dx.doi.org/10.21831/pg.v10i2.9163 


\section{PENDAHULUAN}

Perkembangan dan kemajuan ilmu pengetahuan dan teknologi sekarang ini mengalami peningkatan yang sangat pesat, termasuk di dalamnya bidang pendidikan. Target peningkatan kualitas pendidikan banyak dilakukan pada perbaikan materi kurikulum, proses pembelajaran, penilaian, perlengkapan sarana dan prasarana serta kualitas guru.

Menurut Zamroni (2000, p.120), kebijakan dan program peningkatan kualitas guru dalam melaksanakan proses belajar mengajar harus menyentuh tiga aspek yaitu; aspek kemampuan, aspek semangat dan dedikasi dan aspek kesejahteraan. Kebijakan yang tidak lengkap, yang tidak mencakup ketiga aspek tersebut cenderung akan mengalami kegagalan. Kebijakan untuk meningkatkan kualitas guru harus banyak bertumpu pada inisiatif dan kemauan yang datang dari pihak guru sendiri. Guru harus mengembangkan kemampuan untuk belajar. Kemampuan ini akan terus tumbuh jika guru memiliki cukup ruang untuk berinisiatif dan berimprofikasi.

Undang Undang Republik Indonesia Nomor 20 tahun 2003 tentang Sistem Pendidikan Nasional menyatakan bahwa pendidikan adalah usaha sadar dan terencana untuk mewujudkan suasana belajar dan proses pembelajaran agar peserta didik secara aktif mengembangkan potensi dirinya untuk memiliki kekuatan spiritual keagamaan, pengendalian diri, kepribadian, kecerdasan, akhlak mulia serta keterampilan yang diperlukan bagi dirinya, masyarakat, bangsa dan negara. Dalam Peraturan Pemerintah Nomor 65 tahun 2013 tentang Standar Proses menyebutkan bahwa setiap pendidik pada satuan pendidikan berkewajiban menyusun Rencana Pelaksanaan Pembelajaran (RPP) secara lengkap dan sistematis.

Newby, et. al (2000, p.83) mengemukakan bahwa Rencana Pelaksanaan pembelajaran memuat dua fungsi hubungan yang penting yaitu:a)Link betwen the curriculum goal and the student; (b) Link among obyectives, instruksion, and evaluasion. Yakni guru dapat menyesuaikan antara tujuan kurikulum, siswa, pengajar dan evaluasi agar tercipta kesesuaian /keselarasan antara yang satu dengan yang lain.

Dengan demikian, setiap satuan pendidikan perlu melakukan perencanaan pembelajaran, pelaksanaan proses pembelajaran serta penilaian proses pembelajaran dengan strategi untuk me- ningkatkan efisiensi dan efektifitas ketercapaian kompetensi lulusan.

Untuk memudahkan guru dalam melaksanakan pembelajaran dan memudahkan siswa untuk belajar secara mandiri, biasanya kegiatan ini dilengkapi dengan Lembar kegiatan Siswa (LKS), baik yang berbentuk cetak atau atau noncetak. Sebuah Rencana Pelaksanaan Pembelajaran (RPP) harus dilengkapi dengan perangkat penilaian yang dijabarkan dalam bentuk instrumen. Menurut Poppy (2009, p.32), Lembar Kegiatan Siswa (LKS) adalah lembaran-lembaran berisi petunjuk atau langkah-langkah untuk menyelesaikan tugas yang harus dikerjakan oleh siswa.

Sesuai dengan Standar Kompetensi Lulusan sasaran pembelajaran mencakup pengembangan ranah sikap, pengetahuan dan ketrampilan yang dielaborasi untuk setiap satuan pendidikan. Ketiga ranah kompetensi tersebut memiliki lintasan perolehan (proses psikologis) yang berbeda.Sikap diperoleh melalui aktivitas menerima, menjalankan, menghargai, menghayati dan mengamalkan. Pengetahuan diperoleh melalui aktivitas mengingat, memahami, menerapkan, menganalisis, mengevaluasi dan mencipta. Keterampilan diperoleh melalui aktivitas mengamati, menanya, mencoba, menalar, menyaji dan mencipta. Karakteristik kompetensi beserta perbedaan lintasan perolehan turut serta mempengaruhi standar proses.

Dalam Lampiran VI Permen Nomor 81a Tahun 2013 tentang Implementasi Kurikulum Pedoman Umum Pembelajaran menyebutkan bahwa strategi pembelajaran sangat diperlukan dalam menunjang terwujudnya seluruh kompetensi yang dimuat dalam Kurikulum 2013. Untuk mencapai kualitas yang telah dirancang dalam dokumen kurikulum, kegiatan pembelajaran perlu menggunakan prinsip: (1) berpusat pada siswa (2) mengembangkan kreativitas peserta didik (3) menciptakan kondisi menyenangkan dan menantang (4) bermuatan nilai etika, estetika, logika dan kinestika (5) menyediakan pengalaman belajar yang beragam melalui penerapan berbagai strategi dan metode pembelajaran yang menyenangkan kontektual, efektif, efisien dan bermakna. Pelaksanaan pembelajaran harus diawali dengan penyiapan rencana pelaksanaan pembelajaran yang dikembangkan oleh guru baik secara individual atau kelompok MGMP. Rencana Pelaksanaan Pembelajaran tersebut harus mengacu pada silabus.

Masalah pembelajaran berhubungan erat dengan masalah psikologis, menurut Skemp 
(1971. pp. 13-14), masalah dalam pembelajaran dan pengajaran adalah masalah psikologis dan sebelum kita dapat melakukan perbaikan dalam pengajaran, kita harus mengetahui tentang bagaimana cara pembelajaran.

Melaksanakan pembelajaran yang berbasis saintifik harus diawali dengan perubahan pola berpikir baik dari guru, siswa dan tenaga kependidikan serta masyarakat bahwa: (1) guru dan buku bukan satu-satunya sumber belajar; (2) kelas bukan satu satunya tempat belajar, belajar dapat dari lingkungan; (3) guru mengajak siswa mencari tahu bukan memberi tahu; (4) membuat siswa suka bertanya bukan guru yang sering bertanya; (5) menekankan pentingnya kolaborasi (guru dan siswa adalah rekan belajar); (6) mengutamakan proses dari pada hasil; (7) perubahan peran dari teaching ke tutoring; (8) siswa memiliki kekhasan masing masing (Permendikbud No. 66 )

Menurut Buxton \& Provenzo (2007. p. 6), ilmu sebagai cabang cabang studi yang berhubungan dengan fenomena alam semesta material dan hukum mereka. Cabang cabang dari ilmu sains adalah Fisika, Biologi, Kimia, Bumi dan Antariksa.

Bordens \& Abbot (2008.p.2) menyatakan sains dalam pelaksanaannya memerlukan suatu metode ilmiah dalam memecahkan suatu masalah, kemudian masalah tersebut dapat dikembangkan menjadi pengetahuan-pengetahuan yang dapat dipercaya kebenarannya.

Pembelajaran saintifik mempersiapkan anak didik untuk berani dalam berinovasi. Keahlian untuk membangun ide-ide inovatif adalah keahlian kognitif dan berpikir asosiasi. Alasan yang lebih penting adalah agar siswa siswa lebih sering melakukan keahlian berperilaku yaitu bertanya, melakukan pengamatan, melakukan jejaring dan melakukan eksperimen.(Dyers, 2011. p.27)

Dalam Permendiknas nomor 66 tahun 2013 tentang Standar Penilaian Pendidikan disebutkan bahwa penilaian adalah proses pengumpulan dan pengolahan informasi untuk mengukur pencapaian hasil belajar siswa. Guru melakukan penilaian melalui evaluasi yang biasanya berupa tes tertulis untuk mengetahui prestasi belajar siswa.

Nitko \& Brookhart (2011, p.6) mendefinisikan evaluasi sebagai proses membuat pertimbangan nilai tentang produk atau kinerja siswa. Dan juga mendifinisikan " test is an instrument or systematic procedure for observing and describing one or more characteristicsnof a student using either a numerical scale or a classification scheme" Dimaksudkan tes merupakan suatu instrumen atau prosedur sistematik untuk mengobservasi dan mendiskripsikan skala numerik atau skala pengklasifikasian (Nitko \& Brookhart, 2011, p. 515).

Salah satu pengukuran prestasi siswa adalah dengan melakukan tes. Ebel \& Frisbie (1986: 11) menyatakan bahwa " Test provide the best information teachers and students ordinarily can get about the success of their effort to teach and learn". Maksud pernyataan di atas adalah tes merupakan sumber informasi terbaik bagi guru maupun siswa mengenai kesuksesan dalam kegiatan belajar mengajar. Kemampuan siswa dalam menyelesaikan soal atau menjawab pertanyaan secara tepat menunjukkan tingkat penguasaan siswa terhadap materi dan indikator kompetensi yang ditetapkan.

Peran guru sebagai fasilitator harus mampu mengemas kegiatan pembelajaran menjadi efektif, efisien, ilmiah dan menyena ngkan. Kegiatan pembelajaran diharapkan dapat membekali siswa agar memiliki kesiapan untuk menghadapi tantangan kehidupan di masyarakat dalam memecahkan masalah yang cepat dan tepat.

Dijelaskan oleh Nitko \& Brookhart (2011, p. 22) bahwa: "Problem solving revers to the kind of thinking required when reaching A goal is not automatic and student must use one of more higher order thinking processes to do it'. Setiap siswa akan menemui masalah ketika mereka ingin menggapai tujuan tertentu tetapi tidak otomatis dan siswa harus menggunakan satu atau lebih berpikir tingkat tinggi untuk menyelesaikannya. NCTM (2000, p.334), menjelaskan bahwa pemecahan masalah meliputi kepercayaan diri dan kesediaan untuk menyelesaikan masalah baru atau masalah yang sulit.

Menurut Foshay, Rob and Kirkley (2003) pemecahan masalah merupakan kemampuan dasar yang harus dimiliki oleh seorang siswa. Pendidik dan praktisi pendidikan dewasa ini menyusun kembali kurikulum yang didalamnya termasuk integrasi lingkungan pembelajaran yang mendorong siswa untuk menggunakan kemampuan berpikir yang lebh tinggi, dan khususnya kemampuan pemecahan masalah.

Pemecahan masalah dan pembelajaran sering kita temui dalam beberapa kasus penelitian diantaranya penelitian oleh Effendi (2012) yang menyatakan bahwa perbedaan pembelajaran memberikan pengaruh yang signifikan terhadap peningkatan kemampuan pemecahan 
masalah siswa. Siswa yang mendapatkan pembelajaran dengan metode penemuan terbimbing lebih baik dari pada pembelajaran konvensional.

Terdapat beberapa penelitian yang menjadikan kemampuan pemecahan masalah menjadi topik utama. Salah satunya adalah penelitian Aliyah (2014, pp.10-18) yang membandingkan keefektifan antara metode Resources Based Learning dan Problem Based Learning dalam menilai kemampuan pemecahan masalah. Didapatkan hasil bahwa penerapan Resources Based Learning lebih baik daripada metode Problem Based Learning. Sedangkan menurut penelitian Setiawan \& Harta (2014, pp.240256), pendekatan open-ended lebih efektif dibandingkan dengan pendekatan kontekstual pada aspek kemampuan pemecahan masalah.

Kurikulum 2013 mengamanatkan siswa untuk mampu dan memiliki bekal sikap, pengetahuan dan ketrampilan yang cukup dalam penyelesaian masalah dalam kehidupan. Dengan demikian, guru harus mampu merancang perangkat pembelajaran yang mampu memberikan pengalaman belajar kepada siswa. Dalam menyiapkan kemampuan guru untuk merancang dan melaksanakan pembelajaran saintifik serta melaksanakan penilaian autentik menggunakan silabus sebagai acuan, perlu penjabaran operasional dalam mengembangkan materi dan langkah-langkah pembelajaran, sehingga diperlukan rambu rambu yang bisa menfasilitasi guru dalam menyikapi, menyamakan presepsi dan pemahaman dalam membuat perangkat pembelajaran pembelajaran. Perangkat pembelajaran ini terdiri atas Silabus, Rencana Pelaksanaan Pembelajaran (RPP), Lembar Kegiatan Siswa (LKS) dan Tes Prestasi Belajar (TPB), untuk itu penulis berkesimpulan bahwa penting sekali mengembangkan perangkat pembelajaran matematika berbasis saintifik untuk meningkatkan kemampuan pemecahan masalah dan prestasi belajar dikelas X SMA semester dua.

\section{METODE}

Jenis penelitian ini adalah penelitian pengembangan. Penelitian ini difokuskan pada pengembangan produk berupa perangkat pembelajaran matematika berbasis saintifik untuk meningkatkan kemampuan pemecahan masalah dan prestasi belajar siswa. Produk yang dikembangkan yaitu Rencana Pelaksanaan Pembelajaran (RPP), Lembar Kegiatan Siswa (LKS), Tes Pemecahan Masalah dan Tes Prestasi Belajar (TPB).
Subjek penelitian ini adalah siswa siswa kelas X SMA Negeri 2 Yogyakarta terutama kelas X.PMIIA1-X.PMIIA3 dan XPMIIA8. Waktu penelitian adalah semester 2 tahun pelajaran 2014-2015.

Menurut Desai \& Potter (2006, p.3), "the aim of Doing Development Research is to provide a comprehensive introduction to the process of undertaking research in the multi and interdisciplinary field of development studies". Hal ini menunjukkan bahwa tujuan melakukan penelitian pengembangan adalah sebagai pengantar yang komprehensif apabila akan dilakukannya suatu proses penelitian pada tingkatan yang lebih komplek.

Prototipe pengembangan penelitian ini dilakukan adaptasi dari model pengembangan Borg dan Gall dengan dilakukan beberapa modifikasi sesuai dengan kondisi pada penelitian ini. Dari sepuluh tahap pengembangan model Borg dan Gall dimodivikasi menjadi tiga tahap penelitian, yaitu meliputi define, design dan develop. Tahap define ini memuat langkah kesatu (Research and information collecting) dan langkah kedua (Planning). Tahap design meliputi langkah ketiga (develop preliminary form of product), langkah keempat (Preliminary field testing) dan langkah kelima (Main Product revision). Pada tahap develop meliputi langkah keenam sampai dengan langkah ke 10 yakni, main field testing, Operational product revision, Operational field testing, Final revision dan Dissemination and implementation.

\section{Prosedur Pengembangan}

Prosedur pengembangan penelitian melalui 3 tahap yaitu; desain Define, Design dan Develop.

\section{Tahap Define}

Pada tahap ini peneliti melakukan pengumpulan informasi-informasi berkaitan dengan produk yang akan dikembangkan. Pengumpulan informasi dilakukan dengan studi pustaka dan studi lapangan,yakni dengan mengumpulkan literatur perencanaan pembelajaran saintifik, catatan pribadi dalam pembelajaran,dan informasi tentang RPP, LKS, Tes Prestasi dan Tes Pemecahan masalah teman guru.

\section{Tahap Design}

Pada tahap design dilakukan beberapa langkah, yaitu (1) menentukan tujuan pengembangan, yaitu mendapatkan perangkat pembelajaran berupa rencana Pelaksanaan Pembelajar- 
an (RPP), Lembar Kegiatan Siswa (LKS), Tes Prestasi Belajar dan Tes Kemampuan Pemecahan Masalah (TKPM). Materi yang dikembangkan perangkatnya adalah persamaan \& fungsi kuadrat dan peluang (2) penyusunan instrumen untuk mengukur kevalidan, kepraktisan dan keefektifan (3) melakukan analisis indikator pada setiap KD (4) penyusunan RPP yang berbasis saintifik dengan pendekatan kooperatif dengan pembelajaran berbasis masalah (5) Penyusunan LKS yang memenuhi tahapan saintifik.

\section{Tahap Develop}

Dari tahap design didapatkan produk yang berupa draf ke-1 yang selanjutnya dilakukan validasi, uji coba terbatas, dan revisi sehingga didapatkan produk yang valid, praktis, dan efektif. Langkah-langkah dalam tahap develop meliputi:

Pertama, Validasi Ahli, produk yang dihasilkan dari tahap ke-2 selanjutnya dilakukan validasi oleh dua ahli materi dan seorang validasi instrumen sehingga dapat diketahui apakah produk yang dihasilkan telah sesuai dan layak digunakan dan alat ukur yang digunakan sudah memenuhi syarat atau belum. Selain untuk mengetahui kevalidan produk, validasi juga bertujuan untuk mengetahui kelayakan instrumen yang akan digunakan untuk mengukur kevalidan, kepraktisan, dan keefektifan produk. Selain itu juga validasi bertujuan untuk mendapatkan masukan, dan saran perbaikan atas produk dan instrumen yang terbentuk.

Setelah dilakukan validasi oleh para ahli, selanjutnya akan dilakukan analisis terhadap hasil validasi. Apabila hasil analisis data produk draf 1 adalah valid, maka produk dapat digunakan dalam uji coba. Apabila valid dan layak dengan sedikit revisi, maka dilakukan revisi seperti yang disarankan oleh para ahli, dan produk yang direvisi dapat digunakan dalam uji coba. Namun jika hasil analisis menunjukan tidak valid dan tidak layak, maka dilakukan revisi besar. Hasil revisi harus divalidasi kembali oleh ahli hingga didapatkan produk revisi yang valid dan layak. Produk revisi hasil validasi ahli ini dinamakan dengan produk draf 2.

Kedua, Uji coba terbatas, produk draf 2 sebagai hasil dari validasi ahli kemudian diujicobakan pada kelompok terbatas yang dinamakan uji coba terbatas. Uji kelompok terbatas dilakukan untuk menguji kualitas produk pengembangan pada skala kecil. Yaitu meliputi keterbacaan dan pelaksanaan pembelajaran yang menggunakan produk draf 2. Setelah dilakukan uji coba terbatas, selanjutnya akan dilakukan analisis dari hasil uji coba tersebut. Apabila hasil dari uji coba terbatas membutuhkan perbaikan, maka produk dilakukan revisi. Produk revisi hasil uji coba terbatas ini dinamakan dengan produk draf 3 , dan selanjutnya dilakukan uji coba lapangan.

Ketiga, uji coba lapangan, uji coba lapangan ini bertujuan untuk mengetahui kepraktisan dan keefektifan produk. Uji coba lapangan dilakukan untuk menguji kualitas produk pengembangan pada skala yang lebih besar. Kepraktisan produk dapat diketahui dari data penilaian guru, angket respon siswa dan lembar observasi pelaksanaan pembelajaran di kelas. Keefektifan produk dapat diketahui dari hasil tes prestasi belajar dan hasi tes kemampuan pemecahan masalah.

Data hasil uji lapangan yang telah didapatkan selanjutnya akan dilakukan analisis data sehingga diketahui kepraktisan dan keefektifan produk. Apabila hasil analisis data telah memenuhi kriteria kepraktisan dan keefektifan, maka produk tersebut adalah produk akhir. Jika hasil analisis menunjukkan belum memenuhi kriteria kepraktisan dan keefektifan,maka dilakukan revisi produk kembali.

Jenis data dalam penelitian ini meliputi data kuantitatif dan data kualitatif. Data-data ini bertujuan untuk memberi gambaran mengenai kualitas produk yang dikembangkan. Data kuantitatif diperoleh dari validasi ahli, lembar penilaian guru, lembar observasi, angket respon guru, angket respon siswa, dan tes hasil belajar. Skor data kuantitatif dikonversi menjadi data kualitatif untuk menentukan kriteria dari suatu produk.

Instrumen yang digunakan pada penelitian ini yaitu untuk mengumpulkan data tentang kategori kevalidan, kepraktisan, dan keefektifan produk. Instrumen yang digunakan dalam penelitian ini meliputi: Instrumen Validasi Format validasi Perangkat Pembelajaran dan Instrumen penelitian yang memberikan penilaian pada aspek prosedur, isi dan bahasa. Instrumen Penilaian Kevalidan, yang terdiri dari lembar validasi RPP, lembar validasi LKS, lembar validasi pre dan pos tes prestasi belajar, lembar validasi posttest kemampuan pemecahan masalah. Instrumen Penilaian Kepraktisan terdiri dari lembar penilaian guru, lembar respon siswa, lembar observasi keterlaksanaan pembelajaran daik dari kegiatan guru ataupun dari kegiatan siswa. Instumen Penilaian Keefektifan terdiri 
dari tes prestasi belajar dan tes kemampuan pemecahan masalah.

Teknik analisis data pada penelitian ini adalah untuk menentukan apakah produk yang dikembangkan memenuhi syarat kevalidan, kepraktisan, dan keefektifan. Jika syarat-syarat terpenuhi maka didapatkan produk yang berkualitas. Data yang didapatkan dalam penelitian ini yaitu data yang bersumber dari lembar validasi, lembar penilaian guru, lembar observasi, angket respon siswa, TPB dan TKPM. Teknik analisis dari data yang didapatkan adalah sebagai berikut:

Secara umum teknik analisis dari data tersebut yaitu data yang didapatkan dikelompokkan berdasarkan kualifikasi produk yang akan dinilai. Dilakukan perhitungan rata-rata atas data yang telah dilakukan pengelompokan. Untuk menghitung rata-rata menggunakan acuan sebagai berikut:

$$
\bar{x}=\frac{\sum x}{n}
$$

Keterangan

$\bar{x}=$ skor rata-rata

$\sum x=$ total skor jawaban,

$\mathrm{n}=$ banyak evaluator

Skor rata-rata yang didapatkan kemudian diubah kedalam kriteria kualitatif dengan ketentuan seperti pada Tabel 1. Dari Tabel 1 yang diadopsi dari Direktorat Pembinaan SMA (2010: 59-60) dapat diketahui kualitas produk yang dikembangkan. Adapun tabel kriteria penilaian skala likert yaitu sebagai berikut:

Tabel 1. Kriteria Penilaian Skala Likert

\begin{tabular}{cc}
\hline Interval & Kriteria \\
\hline$M_{i}+1,8 S D i<\bar{M}$ & $\mathrm{SB}$ \\
$M_{i}+0,6 S D i<\bar{M} \leq M_{i}+1,8 S D i$ & $\mathrm{~B}$ \\
$M_{i}-0,6 S D i<\bar{M} \leq M_{i}+0,6 S D i$ & $\mathrm{C}$ \\
$M_{i}-1,8 S D i<\bar{M} \leq M_{i}-0,6 S D i$ & $\mathrm{~K}$ \\
\hline$M \leq M_{i}-1,8 S D i$ & $\mathrm{SK}$ \\
\hline
\end{tabular}

Keterangan:

$\bar{M}=$ Rata-rata akhir

$M_{i}=$ Rata-rata ideal

$=1 / 2($ skor maksimun ideal + skor minimum ideal $)$

$S D i=$ Standar deviasi ideal

$=\frac{1}{6}($ skor maksimun ideal - skor minimum ideal $)$

Skor maksimal ideal $=\Sigma$ butir kriteria $\times$ skor tertinggi

Skor minimum ideal $=$ butir kriteria $\times$ skor terendah

Perangkat pembelajaran dikatakan valid jika memenuhi kriteria B, Kriteria kualitatif yang digunakan pada lembar validasi ahli adalah sangat valid (A), valid (B), cukup valid (C), kurang valid (D) dan sangat kurang valid (E). Untuk lembar penilaian guru, dan lembar penilaian siswa adalah sangat praktis (A), praktis (B), cukup praktis (C), kurang praktis (D) dan sangat kurang praktis (E).

Data-data hasil penelitian ini akan dianalisis untuk mendapatkan kriteria dari kualitas dari perangkat pembelajaran yang dikembangkan. Analisis data ini dibagi atas 3 kategori yaitu analisis kevalidan perangkat pembelajaran, analisis kepraktisan perangkat pembelajaran dan analisis keefektifan perangkat pembelajaran. Teknik analisis yang digunakan untuk memberikan kriteria kualitas perangkat pembelajaran yang dikembangkan.

\section{HASIL DAN PEMBAHASAN}

Deskripsi hasil pengembangan perangkat pembelajaran dengan menggunakan model pengembangan Borg and Gall yang telah dimodifikasi sesuai dengan kondisi pada penelitian ini. Dari 10 tahap pengembangan Borg and Gall dimodifikasi menjadi 3 tahap penelitian yaitu: define, design dan develop.

\section{Tahap Pendefinisian (Define)}

Pada tahap ini dilakukan kegiatan studi pustaka untuk mengkaji teori dan hasil penelitian terdahulu juga studi lapangan dengan memperhatikan profil sasaran, kekuatan dan kelemahannya. Dengan cara mengidentifikasi tujuan pembelajaran yang ada dalam silabus, dengan melakukan analisis kebutuhan. Dari analisis kebutuhan diperoleh informasi tentang; pentingnya pembelajaran saintifik, realitas pelaksanaan pembelajaran saintifik di lapangan dan pendekatan yang sesuai dalam pembelajaran saintifik.

\section{Tahap Perancangan (Design)}

Pada tahap ini dilakukan kegiatan pemilihan materi pembelajaran, setelah dilakukan diskusi dengan dosen pembimbing maka dipilih materi yang berkaitan dapat dikembangkan dengan pembelajaran saintifik yaitu materi persamaan kuadrat, fungsi kuadrat dan peluang. Perangkat yang akan dirancang adalah Rencana Pelaksanaan Pembelajaran (RPP), Lembar Kegiatan Siswa (LKS), Tes Prestasi Belajar (TPB) dan Tes kemampuan Pemecahan masalah (TKPM).

\section{Tahap Pengembangan (Develop)}

Dalam tahap pengembangan ini dimulai dengan menyusun perangkat pembelajaran 
berupa Rencana Pelaksanaan Pembelajaran (RPP), Lembar Kegiatan Siswa (LKS), Tes Prestasi Belajar (TPB) dan Tes Kemampuan Pemecahan Masalah (TKPM). Setelah perangkat tersebut selesai disusun dan dikonsultasikan dengan dosen pembimbing maka langkah berikutnya adalah melakukan proses validasi ahli,

Validasi Ahli dilakukan untuk melihat isi draf 1. Validasi ini bertujuan untuk mendapatkan masukan, saran perbaikan, dan sekaligus penilaian terhadap draf 1 sebelum dilakukan uji coba terbatas. Kegiatan validasi dilakukan dengan cara memberikan naskah produk draf 1 berupa RPP, LKS, TPB dan TKPM serta lembar validasi kepada dua validator ahli.

Data hasil validasi materi untuk masingmasing komponen produk dapat dilihat pada Tabel 2

Tabel 2. Skor Validasi Perangkat Pembelajaraan

\begin{tabular}{ccccc}
\hline \multirow{2}{*}{ Validator } & \multicolumn{4}{c}{ Skor Produk yang Divalidasi } \\
\cline { 2 - 5 } & RPP & LKS & TPB & TKPM \\
\hline 1 & 151 & 131 & 59 & 59 \\
2 & 141 & 107 & 45 & 48 \\
Skor Total & 292 & 238 & 104 & 107 \\
Rata-rata & 146 & 119 & 52 & 53,5 \\
\hline
\end{tabular}

Berdasarkan data dari validasi ahli, maka dilakukan analisis untuk mengetahui kevalidan/ kelayakan produk yang dikembangkan. Kelayakan produk ini berdasarkan data yang berupa rata-rata skor hasil penilaian dari dua validator. Data dari validator yang berupa data kuantitatif dikonversi kedalam data kualitatif. RPP secara keseluruhan dikatakan valid atau layak digunakan apabila skor rata-rata RPP memenuhi kategori minimal B yaitu $\bar{x} \geq 119$. LKS secara keseluruhan dikatakan valid atau layak digunakan apabila skor rata-rata LKS memenuhi kategori minimal B atau $\bar{x} \geq 102$. TPB secara keseluruhan dikatakan valid atau layak digunakan apabila skor rata-rata TPB memenuhi kategori minimal B atau $\bar{x} \geq 33,6$. TKPM secara keseluruhan dikatakan valid atau layak digunakan apabila skor rata-rata TKPM memenuhi kategori minimal $\mathrm{B}$ atau $\bar{x} \geq 33,6$. Adapun skor aktual, rata-rata skor, dan kategori dari setiap produk yang diperoleh disajikan pada Tabel 3.

Tabel 2. Analisis Kevalidan Perangkat Pembelajaran

\begin{tabular}{cccc}
\hline Produk & Skor aktual & rata-rata & Kategori \\
\hline RPP & 292 & 146 & $\mathrm{~B}$ \\
LKS & 238 & 119 & $\mathrm{~B}$ \\
TPB & 104 & 52 & $\mathrm{~A}$ \\
TKPM & 107 & 53,5 & $\mathrm{~A}$ \\
\hline
\end{tabular}

Perangkat pembelajaran (RPP, LKS, TPB dan TKPM) draf 3 sebelum diujicobakan lapangan dimintakan penilaian beberapa guru, 2 guru pelaksana uji coba dan 3 guru observer. Data hasil penilaian perangkat pembelajaran oleh guru yang berupa data kuantitatif dikonversi menjadi data kualitatif untuk menentukan kategori dari kepraktisan perangkat pembelajaran. Perangkat pembelajaran dikatakan praktis jika skor rata-rata perangkat pembelajaran memenuhi kategori minimal praktis, yaitu $\bar{x} \geq$ 102. Hasil analisis penilaian perangkat pembelajaran oleh guru dalam Tabel 4 .

Tabel 4. Hasil Analisis Perangkat Pembelajaran oleh Guru

\begin{tabular}{cc}
\hline Guru & $\begin{array}{c}\text { Skor Penilaian } \\
\text { Perangkat Pembelajaran }\end{array}$ \\
\hline 1 & 133 \\
2 & 125 \\
3 & 120 \\
4 & 122 \\
5 & 132 \\
Skor Total & 632 \\
Rata-rata & 126,4 \\
Kategori & A \\
\hline
\end{tabular}

Berdasarkan analisis dari data pada Tabel 4 dapat disimpulkan bahwa kepraktisan perangkat pembelajaran mendapatkan skor rata-rata 126,4. Rata-rata ini termasuk dalam kategori sangat praktis atau kategori A. Sedangkan penilaian masing masing perangkat pembelajaran disajikan dalam Tabel 5.

Tabel 5. Hasil Analisis Penilaian Guru Setiap Perangkat Pembelajaran.

\begin{tabular}{ccccc}
\hline \multirow{2}{*}{ Guru } & \multicolumn{4}{c}{ Skor Perangkat } \\
\cline { 2 - 5 } & RPP & LKS & TPB & TKPM \\
\hline 1 & 35 & 34 & 32 & 32 \\
2 & 34 & 35 & 28 & 28 \\
3 & 32 & 32 & 28 & 28 \\
4 & 34 & 34 & 28 & 28 \\
5 & 35 & 35 & 31 & 31 \\
Skor Total & 169 & 170 & 147 & 147 \\
Rata-rata & 33,8 & 34 & 29,4 & 29,4 \\
Kategori & $\mathrm{A}$ & $\mathrm{A}$ & $\mathrm{B}$ & $\mathrm{B}$ \\
\hline
\end{tabular}

Berdasarkan hasil analisis penilaian guru terhadap masing-masing perangkat pembelajaran dari Tabel 5, menunjukkan bahwa masing masing perangkat pembelajaran mencapai kategori B untuk RPP dan LKS, mencapai kategori A untuk TPB dan TKPM atau minimal baik sehingga berada dalam kategori praktis dan sangat praktis. 
Data Lembar Respon/Tanggapan Siswa merupakan data kuantitatif yang dikonversi menjadi data kualitatif untuk menentukan kriteria kepraktisan perangkat pembelajaran. Perangkat pembelajaran dikatakan praktis apabila skor rata-rata perangkat pembelajaran berada dalam kategori minimal praktis atau B yaitu $\bar{x} \geq 54,4$ untuk pembelajaran dan $\bar{x} \geq 46,7$ untuk LKS. Hasil analisis kepraktisan perangkat pembelajaran berdasarkan respon siswa disajikan dalam Tabel 6.

Tabel 6. Analisis Respon Siswa terhadap Perangkat Pembelajaran

\begin{tabular}{ccc}
\hline & \multicolumn{2}{c}{ ASPEK } \\
\hline & Pembelajaran & LKS \\
\hline Skor Total & 5109 & 4495 \\
Rata-rata & 59,41 & 52,27 \\
Kategori & $\mathrm{B}$ & $\mathrm{B}$ \\
\hline
\end{tabular}

Berdasarkan hasil analisis pada Tabel 6 didapatkan bahwa skor rata rata terhadap kegiatan pembelajaran sebesar 59,4 dan LKS sebesar 52,27 . Nilai tersebut berada dalam kategori praktis atau B.

Analisis data hasil observasi keterlaksanaan pembelajara diperoleh dari hasil observasi keterlaksanaan pembelajaran pada setiap pertemuan. Observasi keterlaksanaan pembelajaran ini meliputi observasi kegiatan guru dan observasi kegiatan siswa. Data observasi kegiatan siswa dalam 9 pertemuan disajikan dalam tabel dapat dilihat Tabel 7.

Tabel 7. Hasil Analisis Data Observasi Kegiatan Siswa dalam Pembelajaran

\begin{tabular}{cccc}
\hline Pertemuan & Skor & Persentase $(\%)$ & Kategori \\
\hline 1 & 29 & 82,8 & $\mathrm{~B}$ \\
2 & 30 & 85,7 & $\mathrm{SB}$ \\
3 & 28 & 80 & $\mathrm{~B}$ \\
4 & 29 & 82,8 & $\mathrm{~B}$ \\
5 & 28 & 80 & $\mathrm{~B}$ \\
6 & 30 & 85,7 & $\mathrm{SB}$ \\
7 & 29 & 82,8 & $\mathrm{~B}$ \\
8 & 30 & 85,7 & $\mathrm{SB}$ \\
9 & 32 & 91,4 & $\mathrm{SB}$ \\
Skor Total & 265 & 84,12 & $\mathrm{~B}$ \\
\hline
\end{tabular}

Berdasarkan Tabel 7 pada setiap pertemuan, kegiatan siswa berkategori B dan A atau minimal baik. Prosentase keterlaksanaan pembelajaran dari pertemuan ke 1 sampai dengan pertemuan ke 9, semua diatas atau sama dengan $80 \%$. Hal ini berarti bahwa produk yang dikembangkan praktis digunakan dalam pembelajaran. Apabila dilihat dari aspek yang dinilai maka analisis hasil observasi kegiatan siswa dapat dilihat pada Tabel 8.

Tabel 8. Analisis Hasil Observasi Kegiatan Siswa Berdasarkan Aspek yang Dinilai

\begin{tabular}{cccc}
\hline Aspek & $\begin{array}{c}\text { Jumlah } \\
\text { Skor }\end{array}$ & $\mathbf{( \% )}$ & Kategori \\
\hline Keg, Individu & 111 & 82 & $\mathrm{~B}$ \\
Aktivitas kelompok & 77 & 85 & $\mathrm{~B}$ \\
Aktivitas dg.guru & 77 & 85 & $\mathrm{~B}$ \\
\hline
\end{tabular}

Berdasarkan Tabel 8 dapat disimpulkan bahwa masing-masing aspek yang dinilai mencapai kategori B atau minimal baik. Presentase keterlaksanaan pembelajaran adalah diatas $80 \%$. Hal ini berarti bahwa produk yang dikembangkan praktis digunakan dalam pembelajaran.

Hasil analisis data observasi kegiatan guru pada uji coba terbatas dapat dilihat pada Tabel 9.

Tabel 9.Analisis Hasil Observasi Kegiatan Guru

\begin{tabular}{cccc}
\hline Pertemuan & Skor & Persentase (\%) & Kategori \\
\hline 1 & 92 & 80 & $\mathrm{~B}$ \\
2 & 93 & 80,8 & $\mathrm{~B}$ \\
3 & 99 & 86 & $\mathrm{SB}$ \\
4 & 94 & 81,7 & $\mathrm{~B}$ \\
5 & 94 & 81,7 & $\mathrm{~B}$ \\
6 & 95 & 82,6 & $\mathrm{~B}$ \\
7 & 98 & 85,2 & $\mathrm{SB}$ \\
8 & 92 & 80 & $\mathrm{~B}$ \\
9 & 101 & 87,8 & $\mathrm{SB}$ \\
Skor Total & $\mathbf{6 4 0}$ & $\mathbf{8 2 , 8}$ & $\mathrm{B}$ \\
\hline
\end{tabular}

Berdasarkan Tabel 9 dapat disimpulkan bahwa di setiap pertemuan, kegiatan guru berkategori B dan SB atau minimal baik. Presentase keterlaksanaan pembelajaran adalah $82,8 \%$ atau diatas $80 \%$. Hal ini berarti bahwa produk yang dikembangkan praktis digunakan dalam pembelajaran.

Apabila dilihat dari aspek yang dinilai maka presentase hasil observasi kegiatan guru pada uji coba terbatas dapat dilihat pada Tabel 10.

Tabel 10. Analisis Hasil Observasi Kegiatan Guru Berdasarkan Aspek yang Dinilai

\begin{tabular}{lccc}
\hline Aspek yang Dinilai & $\begin{array}{c}\text { Jumlah } \\
\text { Skor }\end{array}$ & $\mathbf{( \% )}$ & Kategori \\
\hline Kegiatan Awal & 187 & 83 & $\mathrm{~B}$ \\
Kegiatan Inti & 551 & 81 & $\mathrm{~B}$ \\
Kegiatan Akhir & 120 & 88 & SB \\
\hline
\end{tabular}

Berdasarkan Tabel 10 dapat disimpulkan bahwa masing-masing aspek yang dinilai mencapai kategori B dan SB atau minimal baik. Presentase keterlaksanaan diatas $80 \%$. Hal ini 
berarti bahwa produk yang dikembangkan praktis digunakan dalam pembelajaran.

Keefektifan perangkat pembelajaran yang dikembangkan atau produk yang dihasilkan pada penelitian ini didasarkan pada data hasil tes prestasi belajar siswa dan tes kemampuan pemecahan masalah. Aspek prestasi belajar siswa diukur dari hasil TPB, pencapaian ketuntasan belajar siswa secara individual dan presentase ketuntasan secara klasikal yaitu sebanyak $75 \%$ dari jumlah siswa dalam satu kelas telah memenuhi kriteria ketuntasan minimal (KKM).

Data hasil tes prestasi belajar siswa disajikan pada Tabel 11.

Tabel 11. Hasil Analisis

Data Tes Prestasi Belajar

\begin{tabular}{lcccc}
\hline Kelas & $\begin{array}{c}\text { Nilai } \\
\text { Rata-rata }\end{array}$ & $\begin{array}{c}\text { Jumlah } \\
\text { siswa }\end{array}$ & $\begin{array}{c}\text { Jumlah } \\
\text { Siswa }\end{array}$ & $\begin{array}{c}\text { (\%) siswa } \\
\text { tuntas }\end{array}$ \\
\hline $\mathrm{X} . \mathrm{A}_{1}$ & 80,25 & 31 & 33 & 93,9 \\
$\mathrm{X} . \mathrm{A}_{2}$ & 84,76 & 30 & 32 & 93,75 \\
$\mathrm{X} . \mathrm{A}_{8}$ & 82,50 & 31 & 32 & 96,8 \\
\hline
\end{tabular}

Sedangkan persentase ketuntasannya kelas X.PMIA1 mencapai 93,9\%, kelas X.PMIA2 sebesar 93,75\% dan tertinggi di kelas X.PMIA8 sebesar 96,8\%. Hasil analisis data tersebut menunjukkan bahwa presentase siswa yang mencapai KKM lebih dari 75\%. Hasil ini selaras dengan penelitian yang dilakukan oleh Wijayanti (2014), yang menerapkan Pendekatan Saintifik dengan PBL untuk meningkatkan kemampuan pemecahan masalah matematika di kelas X.MIA 2 SMA Negeri Banjar. Sehingga dapat disimpulkan bahwa perangkat pembelajaran yang dikembangkan telah mencapai kriteria efektif.

Hasil tes kemampuan pemecahan masalah ditinjau dari hasil tes yang berbentuk soal uraian yang memuat materi aplikasi dari materi peluang. Tes ini mengukur kemampuan memecahkan masalah yang berupa soal terapan dari permasalahan yang kompleks. Hasil Tes kemampuan pemecahan masalah dapat dilihat dari Tabel 11.

Tabel 12. Hasil Analisis Tes Kemampuan Pemecahan Masalah

\begin{tabular}{ccccc}
\hline Kelas & $\begin{array}{c}\text { Jmh } \\
\text { Siswa }\end{array}$ & $\begin{array}{c}\text { Rata- } \\
\text { rata } \\
\text { Pretes }\end{array}$ & $\begin{array}{c}\text { Rata-rata } \\
\text { Posttest }\end{array}$ & $\begin{array}{c}\text { Kenaikan } \\
(\%)\end{array}$ \\
\hline X.A $A_{1}$ & 33 & 70 & 87 & 17 \\
X.A & 32 & 74 & 94 & 20 \\
X.A $_{8}$ & 32 & 72 & 92 & 20 \\
Jumlah & 97 & 72 & 91 & 19 \\
\hline
\end{tabular}

Berdasarkan hasil pretes dan posttest dari tes kemampuan pemecahan masalah dari jumlah rata-rata dari tiga kelas pelaksana uji coba lapangan diperoleh peningkatan hasil dari pretes ke posttest sebanyak $19 \%$. Sehingga disimpulkan bahwa perangkat pembelajaran yang dikembangkan dapat meningkatkan kemampuan pemecahan masalah siswa atau memenuhi kriteria efektif.

\section{SIMPULAN DAN SARAN}

\section{Simpulan}

Berdasarkan hasil penelitian dan pembahasan diperoleh simpulan sebagai berikut: Semua produk hasil pengembangan perangkat pembelajaran matematika berbasis saintifik untuk meningkatkan kemampuan pemecahan masalah dan prestasi belajar siswa di SMA kelas $X$ meliputi Rencana Pelaksanaan Pembelajaran (RPP), Lembar Kegiatan Siswa (LKS), Tes Prestasi Belajar (TPB) dan Tes kemampuan Pemecahan Masalah (TKPM) setelah melalui tahap validasi maka disimpulkan bahwa produk tersebut valid, dan setelah melalui tahap uji coba lapangan maka disimpulkan bahwa produk tersebut praktis baik ditinjau dari penilaian guru, angket respon siswa, dan keterlaksanaan pembelajaran yang dapat dilihat dari observasi kegiatan guru dan observasi kegiatan siswa. Ditinjau dari ketuntasan prestasi belajar siswa dan kemampuan pemecahan masalah mengalami peningkatan sebelum dan sesudah perlakuan maka disimpulkan bahwa produk tersebut efektif.

\section{Saran}

Berdasarkan kesimpulan yang dikemukakan, maka beberapa saran yang perlu dipertimbangkan untuk peningkatan kualitas pembelajaran matematika sekolah sebagai berikut:

Bagi guru SMA, karena proses pembelajaran saintifik ini tidak bisa dikembangkan untuk setiap topik atau materi maka disarankan untuk dapat mengidentifikasi materi-materi dan dapat mengembangkan perencanaan pembelajaran dan semua komponen perangkatnya.

Produk/Perangkat pembelajaran yang telah dikembangkan ini dapat dijadikan sebagai contoh/referensi pembelajaran matematika yang berbasis saintifik untuk meningkatkan kemampuan pemecahan masalah dan prestasi belajar siswa.

Pembelajaran yang dikembangkan hanya terbatas pada materi pokok persaman kuadrat, 
fungsi kuadrat dan peluang maka disarankan kepada peneliti lain untuk mengembangkannya pada materi pokok yang lain atau dengan metode pembelajaran yang berbeda.

\section{DAFTAR PUSTAKA}

Wijayanti, A. (2014). Penerapan pendekatan saintifik problem based learning untuk meningkatkan kemampuan pemecahan masalah matematika siswa kelas X.MIA 2 SMA Negeri Banjar. Prosiding SENDIMAT ke 2 P4TK Matematika 27-28 Nopember 2014

Aliyah, U.H., Suyitno, H., Agoestanto, A. (2014). Keefektifan resource based learning terhadap kemampuan pemecahan masalah peserta didik materi lingkaran. Jurnal Pendidikan Matematika dan Sains Tahun II No 1

Borden, K.S. \& Abbott, B.B. (2008). Reseach design methods. New York, NY: McGraw Hill Companies, Inc

Borg, W.R., \& Gall, M.D. (1983). Educational reseach an introduction. New York, NY: Longman.

Buxton, C.A. \& Provenzo, E.F. (2007). Teaching science in elementary \& middle school. California, CA: SAGE Publication, Inc

Desai, V \& Potter, R.B. (2006). Doing development research. London: Sage Publications.

Dyer, G., \& Christensen. (2011). The innovator's dna mastering the five skill of disruptiv innovator. Boston, MA: Harvard business review press

Ebel, R. L., \& Frisbie, D. A. (1986). Essentials of educational measurement ( $4^{\text {th }} \mathrm{ed}$.). Englewood Cliffs, NJ: Prentice-Hall, Inc.

Effendi, L.A. 2012. Pembelajaran Matematika dengan metode penemuan terbimbing untuk meningkatan kemampuan representasi dan pemecahan masalah matematis siswa SMP. Jurnal Penelitian Pendidikan 13 (2):1-10)

NCTM. (2000). Principles and standards for school mathematics. Virginia, VA: The National Council of Teachers of Mathematics, Inc.

Nieveen, N., et al. (1999). Prototyping to reach product quality. London: Kluwer Academic Publisher.

Newby, T.J., et al. (2000). Instructional technology for teaching and learning: designing instruction, integrating computers, and usong media. Columbus, OH: Merill

Nitko, A.J., \& Brookhart, S.M. (2011). Educational assessment of students. Columbus, $\mathrm{OH}$ : Merill.

Peraturan Pemerintah RI Nomor 81 a Tahun 2013 Tentang Implementasi kurikulum pedoman umum pembelajaran. Depdiknas.

Permendiknas No 65 tahun 2013 Tentang Standar proses pendidikan dasar dan menengah.

Poppy, S., \& Khaeruddin. (2009). Pengembangan perangkat pembelajaran untuk guru SMP. Bandung. P4TK IPA

Setiawan, R., \& Harta, I. (2014). Pengaruh pendekatan open-ended dan pendekatan kontekstual terhadap kemampuan pemecahan masalah dan sikap siswa terhadap matematika. Jurnal Riset Pendidikan Matematika, 1(2), 241-257. doi:http://dx.doi.org/10.21831/jrpm.v1i2. 2679

Skemp, R. (1971). The psychology of learning mathematics. Baltimore: Routledge

Zamroni. (2000). Paradigma pendidikan masa depan. Yogyakarta: Bigraf Publising. 